\title{
No evidence of genetic heterogeneity in dominant optic atrophy
}

Dominique Bonneau, Eric Souied, Sylvie Gerber, Jean-Michel Rozet, Esther D'Haens, Hubert Journel, Ghislaine Plessis, Jean Weissenbach, Arnold Munnich, Josseline Kaplan

\begin{abstract}
Autosomal dominant optic atrophy (OPA, MIM 165500) is an eye disease causing a variable reduction of visual acuity with an insidious onset in the first six years of life. It is associated with a central scotoma and an acquired blue-yellow dyschromatopsia. A gene for dominant optic atrophy (OPA1) has recently been mapped to chromosome 3q in three large Danish pedigrees. Here, we confirm the mapping of OPA1 to chromosome 3q28-qter by showing close linkage of the disease locus to three recently reported microsatellite DNA markers in the interval defined by loci D3S1314 and D3S1265 in four French families (Zmax = $5 \cdot 13$ at $\theta=0$ for probe AFM 308yfl at locus D3S1601). Multipoint analysis supports the mapping of the disease gene to the genetic interval defined by loci D3S1314 and D3S1265. The present study provides three new markers closely linked to the disease gene for future genetic studies in OPA.
\end{abstract}

(f Med Genet 1995;32:951-953)

Service de Génétique et Unité de

Recherches sur les

Handicaps Génétiques de l'Enfant,

INSERM U393,

Hôpital des

Enfants Malades,

149 rue de Sèvres,

75743 Paris,

Cedex 15, France

D Bonneau

E Souied

$S$ Gerber

J M Rozet

E D'Haens

A Munnich

J Kaplan

Service de Génétique, Centre Hospitalier,

56000 Vannes, France

$\mathrm{H}$ Journel

Service de

Cytogénétique,

Centre Hospitalier,

14000 Caen, France

G Plessis

Généthon,

91200 Evry, France

$\mathrm{J}$ Weissenbach

Correspondence to:

Dr Munnich.

Received 17 May 1995

Revised version accepted for publication 12 July 1995
Autosomal dominant optic atrophy (OPA, MIM 165500) and mitochondrially inherited Leber's hereditary optic neuropathy (LHON)

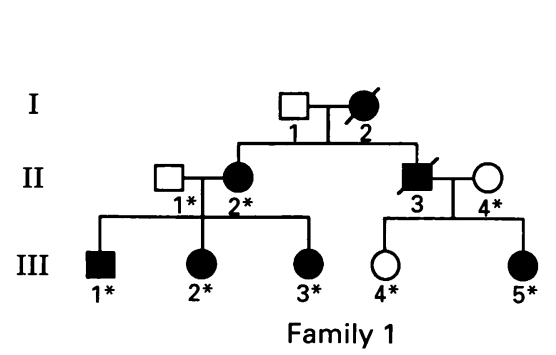

Figure 1 Pedigrees of families with OPA. represent the commonest forms of inherited, uncomplicated optic atrophy. Each disease has an incidence of $1 / 50000 .^{1}$ OPA was originally described by $\mathrm{Kjer}^{2}$ in Danish pedigrees and later by Smith, ${ }^{3}$ Kline and Glaser, ${ }^{4}$ Hoyt, ${ }^{5}$ and Eliott. ${ }^{6}$ The disease usually starts in the first six years of life with a progressive reduction of visual acuity. The visual prognosis is relatively good with stable or slowly progressive visual loss but impairment can vary considerably among affected relatives. ${ }^{6}$ An acquired blueyellow dyschromatopsia with a central, paracentral, or centrocecal scotoma and an inversion of the peripheral field, more confined to blue than to red test objects, are present in most cases. Appearance of the optic nerve ranges from mild temporal pallor to complete atrophy.

Recently, a gene responsible for OPA has been mapped to the distal long arm of chromosome 3 (OPA1, 3q28-qter) by linkage analysis in three large Danish families. ${ }^{7}$ Here, we confirm the localisation of OPA1 to chromosome $3 \mathrm{q}$ in four unrelated French families and provide evidence for genetic homogeneity of this condition.

\section{Materials and methods}

Eighteen affected subjects and 14 healthy relatives belonging to four unrelated families of
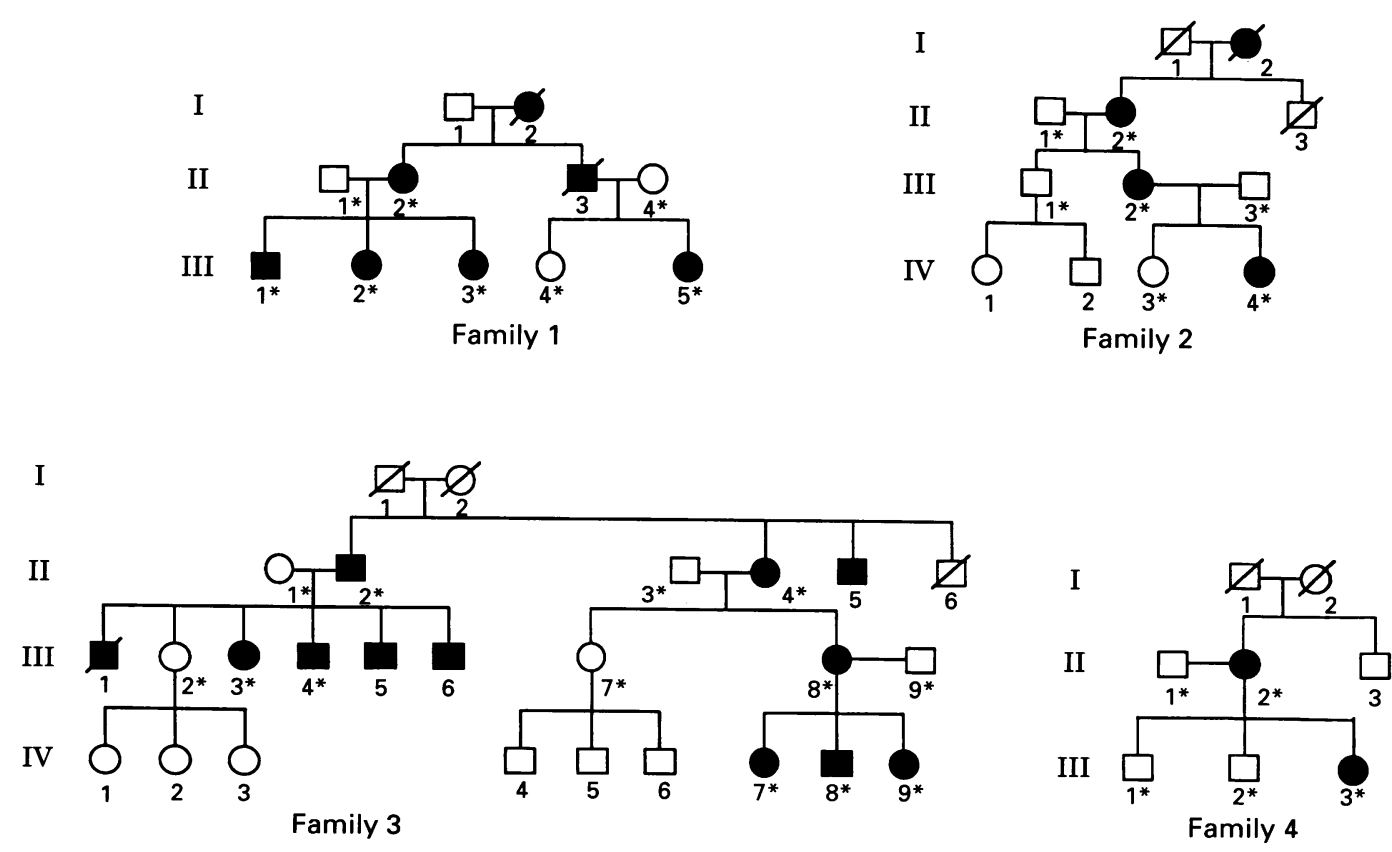
Pairwise lod scores between OPA1 and five polymorphic DNA markers on chromosome $3 q$

\begin{tabular}{|c|c|c|c|c|c|c|c|c|}
\hline \multirow[b]{2}{*}{ Locus } & \multicolumn{6}{|c|}{ Recombination fraction $(\theta)$} & \multirow[b]{2}{*}{$Z \max$} & \multirow[b]{2}{*}{$\theta \max$} \\
\hline & 0 & 0.01 & 0.05 & $0 \cdot 10$ & $0 \cdot 20$ & $0 \cdot 30$ & & \\
\hline $\begin{array}{l}\text { D3S1314 } \\
\text { D3S2747 } \\
\text { D3S1601 } \\
\text { D3S2748 } \\
\text { D3S1265 }\end{array}$ & $\begin{array}{r}-0.82 \\
4.54 \\
5 \cdot 13 \\
2 \cdot 22 \\
-\infty\end{array}$ & $\begin{array}{r}1.52 \\
4.45 \\
5.03 \\
2 \cdot 19 \\
-3.36\end{array}$ & $\begin{array}{r}1.96 \\
4.07 \\
4.60 \\
2.03 \\
-1.40\end{array}$ & $\begin{array}{r}1.91 \\
3.60 \\
4.07 \\
1.81 \\
-0.68\end{array}$ & $\begin{array}{r}1.50 \\
2.60 \\
2.99 \\
1.29 \\
-0.14\end{array}$ & $\begin{array}{l}0.94 \\
1.58 \\
1.84 \\
0.72 \\
0.00\end{array}$ & $\begin{array}{l}1.98 \\
4.54 \\
5 \cdot 13 \\
2 \cdot 22 \\
0.02\end{array}$ & $\begin{array}{l}0.06 \\
0.00 \\
0.00 \\
0.00 \\
0.35\end{array}$ \\
\hline
\end{tabular}

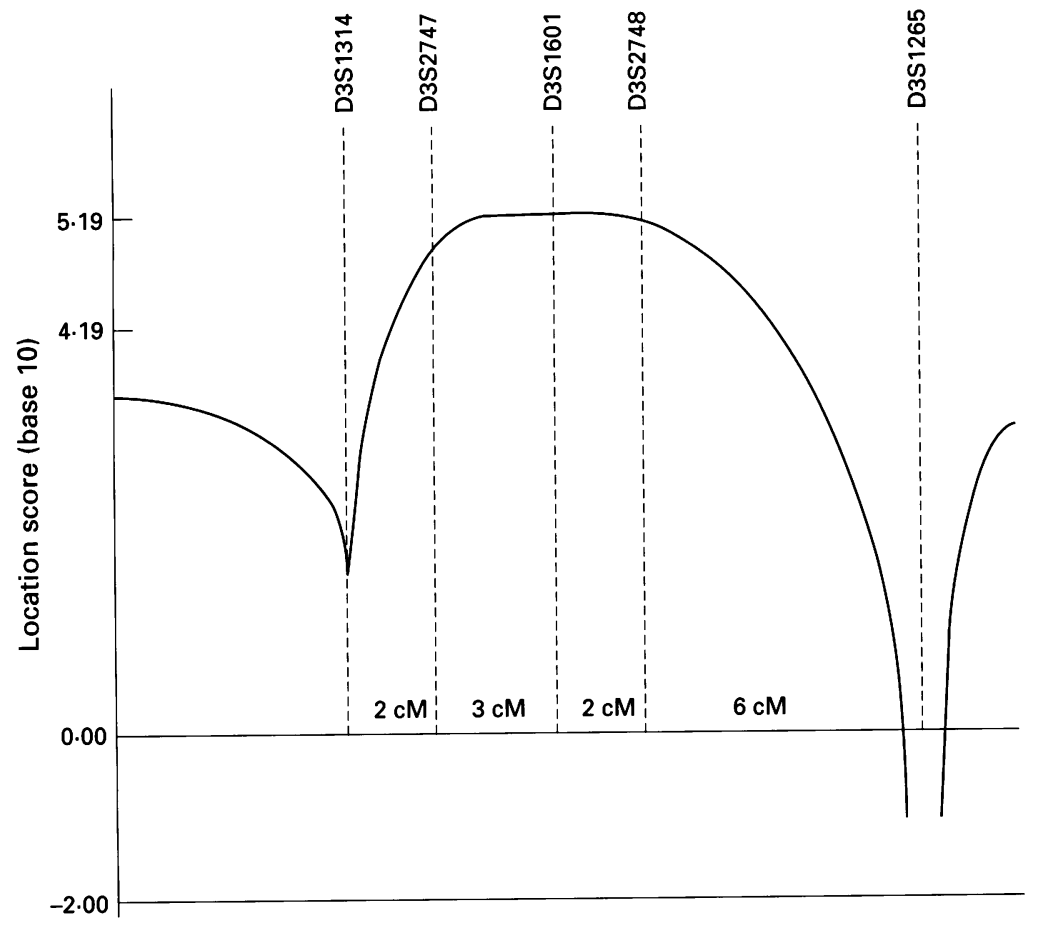

Figure 2 Support for location of OPA1 with respect to five markers on chromosome $3 q$. Likelihood estimates are given in log base 10. Distances between marker loci are shown in cM along the abscissa. amplification using 1 unit Taq polymerase in a buffer containing $50 \mathrm{pmol}$ of each primer, $6.25 \mathrm{nmol}$ of each deoxynucleotide, $50 \mathrm{mmol} / 1$ $\mathrm{KCl}, 10 \mathrm{mmol} / 1$ Tris $\mathrm{HCl}, \mathrm{pH} 8,1.5 \mathrm{mmol} / 1$ $\mathrm{MgCl}_{2}, 0 \cdot 1 \%$ gelatin in a final volume of $50 \mu \mathrm{l}$. Taq polymerase was added after the first step of denaturation ( 10 minutes, $95^{\circ} \mathrm{C}$ ) followed by 30 cycles of denaturation $\left(94^{\circ} \mathrm{C}, 40\right.$ seconds), annealing $\left(55^{\circ} \mathrm{C}, 30\right.$ seconds), and elongation $\left(72^{\circ} \mathrm{C}, 40\right.$ seconds), and a last step of elongation $\left(10\right.$ minutes, $\left.72^{\circ} \mathrm{C}\right)$. An aliquot of the amplified DNA was mixed with the loading buffer. The samples were denatured for 10 minutes at $94^{\circ} \mathrm{C}$ and loaded on a $6 \%$ polyacrylamide denaturing gel. After blotting, nylon membranes were fixed in $0.4 \mathrm{~mol} / 1 \mathrm{NaOH}$ and hybridised for two hours with (CA $)_{12}\left[{ }^{32} \mathrm{P}\right]$ labelled probes. Blots were washed once in $2 \times$ SSC, $0.1 \%$ SDS for 10 minutes at room temperature and autoradiographed.

OPA was tested assuming that the disease is transmitted as an autosomal dominant trait (gene frequency $\mathrm{f}=1 / 50000$ ) with complete penetrance. Linkage analysis was performed using the MLINK and LINKMAP options of the $5 \cdot 1$ version of the LINKAGE package ${ }^{1011}$ using a SUN computer station.

\section{Results}

Linkage analyses using microsatellite DNA markers of chromosome 3 showed a maximum pairwise lod score for marker AFM 308yf1 at the D3S1601 locus $(\mathrm{Zmax}=5 \cdot 13$ at $\theta=0$, table). The location score method was used to estimate the position of the OPAl gene. In this procedure, the map of the marker loci is fixed and the position of the disease locus is varied throughout the map. The order 3pterD3S1314-(0.02)-D3S2747-(0.03)-D3S1601(0.02)-D3S2748-(0.06)-D3S1265-3qter (with recombination estimates in parentheses) has been established by analysis of Généthon markers in CEPH reference families. The maximum likelihood estimate of OPA1 was obtained in the interval defined by loci D3S1314 and D3S1265 (location score in log base $10=5 \cdot 19$, fig 2). A recombination event at locus D3S1265 was observed in one affected member of family 1 and at locus D3S1314 in two affected subjects in family 3 (data not shown). No linkage disequilibrium between OPA and one particular allele was observed with the markers tested. amination. At risk subjects over 10 years were considered as unaffected when their visual acuity was normal with a normal colour vision test and a normal appearance of the fundus. The status of subjects under 10 years of age was considered uncertain when their ophthalmological examination was normal. Those who took part in the linkage study are indicated by an asterisk in fig 1 .

For each person, a $20 \mathrm{ml}$ EDTA blood sample was collected and DNA was prepared from lymphocyte pellets by SDS lysis, proteinase $\mathrm{K}$ digestion, phenol/chloroform extraction, ethanol precipitation, and Tris-EDTA resuspension. The hypervariable microsatellites developed by Weissenbach $e t a l^{8}$ and Gyapay et $a l^{9}$ were used for genotyping. Genomic DNA (50 ng) was submitted to PCR

\section{Discussion}

We report the mapping of a gene for dominant optic atrophy to the long arm of chromosome 3 in four pedigrees of French ancestry. This study gives support to the recent localisation of OPA1 to chromosome 3q28-qter in Danish families. ${ }^{7}$ Eiberg et $a l^{7}$ showed that a disease gene is located in the $10 \mathrm{cM}$ genetic interval defined by loci D3S1314 and D3S1265. The present study gives support to the localisation of the disease gene in this interval and provides no evidence of genetic heterogeneity of OPA, as all families hitherto tested were consistent with linkage to chromosome 3q.

In the last few years, several protein coding 
genes have been mapped to 3q28-qter, including tracheobronchial mucin 4 (MUC4), ${ }^{12}$ melanoma associated antigen p97 (MIF2), ${ }^{13}$ and A-2HS-glycoprotein (AHSG). ${ }^{14}$ None of them can be regarded as candidate genes for OPA1. Continuing studies will help to narrow the genetic interval encompassing the disease gene and hopefully to identify the disease causing gene.

This study was supported by Association Française contre les Myopathies (AFM) and by Groupement de Recherches et d'Etudes sur les Génomes (GREG). Dominique Bonneau is the recipient of a grant from the Région Poitou-Charentes (France).

1 Went LN. Optic atrophy. In: Emery AEH, Rimoin DL, eds. Principles and practice of medical genetics. Edinburgh: Churchill Livingstone, 1990:637-43.

2 Kjer P. Congenital optic atrophy with dominant mode of inheritance. A clinical and genetic study of 19 Danish families. Acta Ophthalmol Suppl 1959;54:1-146.

3 Smith DP. Diagnostic criteria in dominantly inherited juvenile optic atrophy. A report of 3 new families. $A m \mathcal{F}$ Optom 1972;49:183-200.
4 Kline LS, Glaser JS. Dominant optic atrophy. The clinical profile. Arch Ophthalmol 1979;97:1680-6.

5 Hoyt CS. Autosomal dominant optic atrophy. A spectrum of disability. Ophthalmology 1980;87:245-50.

6 Eliott D, Traboulsi EI, Maumenee IH. Visual prognosis in autosomal dominant optic atrophy (Kjer type). Am $\mathcal{F}$ Ophthalmol 1993;115:360-7.

7 Eiberg H, Kjer P, Rosenberg T. Dominant optic atrophy (OPA1) mapped to chromosome 3q region. I. Linkage analysis. Hum Mol Genet 1994;3:977-80.

8 Weissenbach J, Gyapay G, Dib C, et al. A second generation linkage map of the human genome. Nature 1992;359: 794-801.

9 Gyapay G, Morissette J, Vignal A, et al. The 1993-1994 Généthon human genetic linkage map. Nature Genet 1994; 7:246-339.

10 Lathrop GM, Lalouel JM. Easy calculations of lod scores and genetic risks on small computers. Am f Hum Genet 1984;36:460-5.

11 Lathrop GM, Lalouel JM, Julier C, Ott J. Multilocus linkage analysis in human. Detection of linkage and estimation of recombination. Am $\mathcal{F}$ Hum Genet 1985;37:482-98.

12 Nguyen VC, Aubert JP, Gross MS, Porchet N, Degand P, Bernheim A. Tracheobronchial mucin 4 (MUC4) gene assignment to 3q29 and polymorphism VNTR type. Cytoassignment to 3q29 and polymorph.

13 Plowman GD, Brown JP, Enns CA, et al. Assignment of the gene for human melanoma-antigen p97 to chromosome 3 . gene for human melanoma

14 Eiberg H, Mohr J, Nielsen LS. A2HS: new methods of phenotyping and analysis of linkage relations: assignment to chromosome 3. Cytogenet Cell Genet 1984;37:461. 